\title{
As áreas verdes na metrópole do hinterland: parques urbanos no planejamento urbano de Goiânia nas décadas de 1930 e $1940^{1}$
}

\section{Green spaces in the hinterland's Metropolis: parklands in the urban planning of Goiânia during the 1930s and 1940s}

\author{
Anderson Dutra e Silva* \\ Sandro Dutra e Silva*
}

\begin{abstract}
Resumo
Entre as décadas de 1930 e 1940, a expansão da fronteira agrícola e demográfica no Brasil Central criou zonas produtoras de matéria-prima (hinterland) que forneciam produtos agrícolas para as tradicionais regiões "centrais" do sudeste do país. Ao mesmo tempo, o governo procurou criar centros urbanos no Brasil Central com o objetivo de integração econômica e cultural. Este artigo propõe analisar a cidade de Goiânia, a nova capital de Goiás, criada na década de 1930, e considerada pelo Estado Novo (1937-1945), com o símbolo urbano da Marcha para o oeste. Com base nos pressupostos teóricos e metodológicos da história urbana e ambiental, objetivamos analisar os projetos urbanísticos para as áreas verdes na nova capital, e as transformações desses espaços a partir da expansão fundiária do projeto original. Os resultados indicam que o urbanismo progressivo, que norteou a criação de Goiânia, perdeu força frente aos interesses do capital especulativo e o enfraquecimento econômico do governo goiano a partir da década de 1940. Essas mudanças provocaram uma redução dos espaços verdes, e ao mesmo tempo uma expansão fundiária que transformou as paisagens e o projeto original da nova capital goiana.
\end{abstract}

Palavras-chave: urbanismo; história ambiental; parques urbanos; mercado imobiliário.

\footnotetext{
${ }^{1}$ O presente trabalho foi realizado com apoio da Coordenação de Aperfeiçoamento de Pessoal de Nível Superior (Capes), Brasil, sob o Código de Financiamento 001. 0 autor Sandro Dutra e Silva agradece ao Conselho Nacional de Desenvolvimento Científico e Tecnológico (CNPq) a bolsa de produtividade em pesquisa. Sandro Dutra e Silva também agradece o apoio da Universidade Estadual de Goiás pelo apoio e incentivo à projeto de pesquisa científica para o Stricto Sensu intitulado "O Cerrado na mitologia geográfica sedutora: fronteira e natureza na expansão territorial do Brasil Central (séculos XVIII-XIX)”.

"Mestre em Meio Ambiente pelo Centro Universitário de Anápolis. Professor da Pontifícia Universidade Católica de Goiás e do Centro Universitário de Anápolis (UniEvangélica).E-mail: dimdutra74@gmail.com

** Doutor em História Social pela Universidade de Brasília. Professor do Programa de Pós-Graduação em Recursos Naturais do Cerrado da Universidade Estadual de Goiás e do Centro Universitário de Anápolis UniEvangélica. E-mail: sandrodutr@hotmail.com
} 


\begin{abstract}
Between the 1930s and 1940s, the expansion of the agricultural and demographic frontier to Central Brazil created zones dedicated to the production raw materials (hinterland) to supply agricultural goods to the "central" regions of the southeastern country. At the same time, the government sought to create urban centers in Central Brazil to integrate both the economy and culture of the time. Based on the creation of urban centers in the Brazilian hinterland in this period, this article proposes to analyze the city of Goiânia, the new capital of Goiás. Created in the 1930s, the city has historically been part of this project, being considered by the Estado Novo (1937-1945) as an urban symbol of the "March to the West" policy. Supported by the theoretical and methodological assumptions of urban and environmental history, we aim to analyze urban projects for green spaces in the new capital, and the transformations of these areas as a result of the land expansion of the original project. The results indicate that starting in the 1940s, progressive urbanism, which guided the creation of Goiânia, lost strength as the interests of speculative capital became more powerful and the State Government became less influential. These changes caused a reduction of green spaces and an expansion of land and properties that transformed the landscapes of the new capital of Goiás.
\end{abstract}

Keywords: urbanism; environmental history; urban parklands; real estate market.

\title{
Introdução
}

Goiânia foi planejada e construída na década de 1930 como um esforço de substituir a antiga capital do estado de Goiás. O governador Pedro Ludovico Teixeira (1891-1979) havia sido nomeado pelo presidente Getúlio Vargas (1882-1954) como interventor (1930-1945) e coordenou os trabalhos para a criação da nova capital, fundamentada no discurso progressista de cidade "moderna e salubre". A antiga capital, a Cidade de Goiás, era considerada pelo governo estadual como um espaço urbano "insalubre" e cujas características topográficas eram desfavoráveis ao desenvolvimento. ${ }^{2} \mathrm{O}$ interventor era médico e havia concluído sua graduação em 1916 pela Faculdade de Medicina do Rio de Janeiro. Por ser um dos poucos nomes da oposição às oligarquias locais da época, acabou sendo o preferido por Vargas para

\footnotetext{
${ }^{2}$ CAMPOS, Franciso Itami, Mudança da Capital: uma estratégia de poder, in: Goiânia: cidade pensada, Goiânia: Ed. da UFG, 2002, p. 169-184; MANSO, Celina Fernandes Almeida, Goiânia: uma concepção urbana, moderna e contemporânea - um certo olhar, Goiânia: Edição do Autor, 2001.
} 
ocupar o governo de Goiás. O seu background em medicina influenciou para que muitos dos conceitos utilizados na gestão de Goiás fossem decorrentes dessa visão sistemática, levada para a política, em que todos os problemas setoriais deveriam ser examinados, verificados e submetidos aos "devidos tratamentos". ${ }^{3} \mathrm{E}$ esse olhar médico também esteve presente nas orientações urbanas para a nova capital de Goiás.

Esse modo de governar trazia uma nova visão de poder, gerando uma rígida sistematização das ações políticas. Neste contexto, a nova capital foi concebida na época como um projeto para a construção de uma metrópole em uma região predominantemente rural. Goiânia foi pensada e ordenada de forma a transformar o contexto econômico da região com base nos discursos de desenvolvimento. Também procurava inaugurar um novo modo de gestão pública e garantir a perpetuação do novo grupo político, do qual o interventor foi seu principal expoente. 0 discurso da nova gestão pública visava superar o modelo oligárquico agropastoril que dominava a política goiana. Desta forma, uma nova capital - considerada com uma cidade "moderna" em área rural, planejada e ordenada - poderia transformar o atraso econômico em desenvolvimento e ofertar aos cidadãos melhorias urbanas, muito relacionadas aos modelos sanitaristas. ${ }^{4}$

Em um primeiro momento, as relações da cidade com a natureza estavam diretamente ligadas aos potenciais e às limitações que a região era capaz de fornecer. ${ }^{5}$ No caso da Cidade de Goiás, a ausência de água encanada nos edifícios e a dificuldade de instalação de redes de esgoto por conta do terreno rochoso, acidentado e cercado por morros, eram vistos como um impedimento ao seu desenvolvimento. ${ }^{6}$ Já, no caso da região escolhida para construção da nova capital, alguns fatores eram fundamentais como a proximidade da estrada de ferro, a topografia regular de baixa inclinação e os fartos rios e matas existentes, ${ }^{7}$ os quais facilitariam o desenvolvimento de uma "metró-

\footnotetext{
${ }^{3}$ CAMPOS, op. cit.

${ }^{4}$ Ibidem.

${ }^{5}$ DUTRA E SILVA, Anderson; DUTRA E SILVA, Sandro, "A natureza e a modernidade urbana de Goiânia nos discursos da cidade símbolo do Oeste brasileiro (1932-1942)", Historia Crítica, n. 74, p. 65-93, 2019; DUTRA E SILVA, Anderson; DUTRA E SILVA, Sandro; DELLA GIUSTINA, Carlos Christian, "Goiânia e a urbanização do Oeste: demografia, fronteira agrícola, áreas verdes e mananciais", Revista Inclusiones, v. 5, n. EneroMarzo 2018, p. 14-29, 2018.

${ }^{6}$ MANSO, op. cit.; SABINO JUNIOR, Oscar, Goiânia Documentada, São Paulo: Edigraf, 1960; GODOY, Armando Augusto de, Relatório sobre a conveniência da mudança da capital, in: Goiânia: coletânea especialmente editada pelo Instituto Brasileiro de Geografia e Estatística, Rio de Janeiro: Serviço Gráfico IBGE, 1942, p. 13-30.

${ }^{7}$ ALVARES, Geraldo Teixeira, A luta na epopeia de Goiânia, São Paulo: Gráf. Jornal do Brasil, 1942; SABINO JUNIOR, 1960, op. cit.
} 
pole" ordenada, pronta para atender à demanda urbana dos novos tempos. Porém, a natureza deveria ser transformada, e essa geotransformação estava relacionada com a conquista e domínio das potencialidades dos bens naturais a serviço do desenvolvimento. ${ }^{8} \mathrm{Um}$ pensamento comum na época era expandir as fronteiras econômicas, tirando proveito dos recursos naturais vistos como abundantes, para a promoção da conquista territorial e demográfica do Brasil Central. ${ }^{9}$

A partir da segunda metade do século XIX e com grande influência em arquitetos e engenheiros do início do século XX, o urbanismo era um campo recém-criado da arquitetura, cuja relação com o modelo urbano europeu decorria das influências da sociedade industrial. 0 modelo de planificação na América Latina foi muito influenciado pelo modelo urbano adotado para as cidades europeias. $O$ urbanismo latino-americano e seus dilemas tornaram-se parte de questões importantes apresentadas por pensadores como Charles Fourier (1772-1837), Robert Owen (1771-1858) e Thomas Carlyle (1795-1881). ${ }^{10}$ Esses propuseram medidas para solucionar os problemas criados pelo crescimento urbano, construindo debates sobre os modelos de cidades para a América Latina. Dentre os diversos modelos, destacamos a corrente "progressista”, que se baseava na ordenação rígida das funções urbanas, como moradia, trabalho, lazer e cultura. Também, acreditava-se que a cidade deveria ser alternada por espaços vazios e áreas verdes, próprias para a "jardinagem e a educação sistemática do corpo". ${ }^{11}$ Daí, surge a ideia da cidade higiênica, onde haveria a diminuição da mortalidade e os recursos como águas e espaços ajardinados que deveriam ser distribuídos para todos os cidadãos.

É necessário destacar que um desejo de modernização ${ }^{12}$ teve seu crescente no final do século XIX e início do século XX, sendo utilizado como ideal tanto na Europa quanto nas Américas. As feiras mundiais moldaram o modelo

\footnotetext{
${ }^{8}$ Sobre o projeto de geotransformação podemos destacar modelos semelhantes na América Latina, com o objetivo de planificação urbana e rural, fundamentada em discursos de desenvolvimento, ocorridos na primeira metade do século XX. Ver: MONZOTE, Reinaldo Funes. Nuestro viaje a la Luna: La ideia de la transformación de la naturaleza en Cuba durante la Guerra Fria. La Habana, Cuba: Fondo Editorial Casa de Las Américas, 2019.

${ }^{9}$ DUTRA E SILVA; DUTRA E SILVA, 2019, op. cit.; DUTRA E SILVA, Sandro, No Oeste a Terra e Céu: a expansão da fronteira agrícola no Brasil Central, Rio de Janeiro: Mauad X, 2017; DUTRA E SILVA, Sandro, "Nature's revenge: War on the wilderness during the opening of Brazil's 'Last Western Frontier", International Review of Environmental History, v. 5, n. 1, p. 5-21, 2019.

${ }^{10}$ MONZOTE, 2019, op. cit

${ }^{11}$ CHOAY, Françoise, O Urbanismo: utopias e realidades, uma antologia, 7 a ed. São Paulo: Perspectiva, 2015 , p. 8. ${ }^{12}$ BERMAN, Marshal, Tudo que é sólido desmancha no ar - a aventura da modernidade, São Paulo: Companhia de Letras, 1986.
} 
de nova civilização através da troca de experiências entre arquitetos e urbanistas. ${ }^{13}$ A capacidade industrial era considerada como um elemento fundamental na transformação de materiais em bens de consumo, especialmente para novas técnicas construtivas, além das possibilidades criadas pela eletricidade. $\mathrm{Na}$ América Latina, por exemplo, alguns ideais europeus, especialmente de influência francesa, foram aplicados ao planejamento e à modernização de algumas cidades. Como exemplo podemos citar o papel exercido por Jean-Claude Nicolás Forestier (1861-1930), que atuou nos planos urbanos de Buenos Aires (1925) e de Havana (1925-1930). Também citamos as contribuições de Alfred Agache (1875-1959), na criação do plano de renovação urbana para o Rio de Janeiro (1927-1930). O que havia de comum entre esses arquitetos franceses é que, para eles, o urbanismo era uma nova ciência, a qual fez surgir um novo paradigma, baseando-se em questões como circulação, saúde e estética (esta última apoiada no academicismo francês). É possível reconhecer os boulevares em diagonal de Eugène Haussmann (1809-1891) e os parkways de Daniel Burnham (1846-1912) não somente nos três casos descritos anteriormente, mas também em outras cidades latino-americanas no mesmo período. ${ }^{14}$

É certo que, no caso goiano, a influência da capital mineira, Belo Horizonte, que foi projetada entre 1895 e 1897 pelo engenheiro Aarão Reis (1853-1936 $)^{15}$, figurava como um exemplo vivo e contemporâneo de que os esforços da criação de um centro urbano a partir do nada era possível e, ainda, daria suporte ao desenvolvimento econômico. É importante salientar que no início dos anos 1930, a capital construída a partir de um projeto (e não da adaptação de outra povoação existente) dava sinais fascinava indivíduas daquela época. Se a comparação das capitais do passado pudesse ser feita, onde Ouro Preto e a Cidade de Goiás representavam a decadência da economia aurífera, a nova capital de Minas Gerais poderia ser o exemplo do desenvolvimento futuro, mais do que prometido, praticamente garantido. A "metrópole" seria o ponto convergente das produções rurais e a ligação com os outros grandes centros. As vias de transporte, então, fariam a conexão entre os alimentos

\footnotetext{
${ }^{13}$ CRONON, William, Nature's Metropolis: Chicago and the Great West, New York: W. W. Norton \& Co., 1991.

${ }^{14}$ LEJEUNE, Jean-François, "The city as landscape : Jean Claude Nicolas Forestier and great urban works of Havana, 1925-1930", The Journal of Decorative and Propaganda Arts, v. 22, n. 1996, p. 150-185, 1996; SOSA, Marisol Rodríguez, "O Rio de agache e a Havana de Forestier: representações da 'grande cidade', entre a academia e o modernismo", in: , São Paulo: IX Seminário de história da cidade e do urbanismo- São Paulo, 4 a 6 de setembro de 2006, 2006, p. 1-25; SEGRE, Roberto, Mestres e discípulos no urbanismo Buenos Aires e Havana , duas cidades paradigmáticas, in: Urbanismo na América do Sul: circulação de ideias e constituição do campo. 1920-1960, Salvador: UFBA, 2009, p. 93-118; BRUAND, 1997, op. cit.
}

${ }^{15}$ BRUAND, Arquitetura Contemporânea no Brasil. 
e bens primários com os centros de consumo, garantindo tanto ao produtor rural quanto ao empresário aumento nos ganhos financeiros. Em relatório apresentado ao interventor do estado de Goiás no ano de 1933, o engenheiro Armando de Godoy cita que:

Entre nós, há o caso de Belo Horizonte, cuja grande expansão só começou a verificar-se depois que foram construídas as estradas ligando a capital de Minas às zonas mais produtivas do Estado mediterrâneo. A valorização dos lotes foi rápida, sem paralelo em outras cidades mineiras, tendo produzido várias fortunas a venda dos terrenos. ${ }^{16}$

Experiência semelhante viveu o norte paranaense na mesma época. A criação de da ferrovia São Paulo-Paraná permitiu a ampliação das lavouras de café, sendo que o produto poderia ser levado até o porto de Santos, aumentando o volume das exportações. Assim, dá-se o caso notável da cidade de Londrina, originada a partir da compra de terras por investidores representados pelo britânico Lord Lovat (1871-1933), dando origem à Companhia de Terras Norte do Paraná (CTNP). ${ }^{17} \mathrm{O}$ centro urbano se conectaria tanto às fazendas quanto a outras cidades menores nas proximidades. $\mathrm{O}$ ideal da cidade que potencializa o hinterland, sendo o entreposto tanto consumidor (a partir da concentração populacional e pelos hábitos urbanos de consumo) quanto distribuidor dos produtos agrícolas.

No entanto, no início do século XX, a saúde e o bem estar dos cidadãos estava associado à ideia de urbanismo progressista. No Brasil, a Faculdade de Medicina do Rio de Janeiro (FMRJ) figurava como um instituto promotor de uma corrente que ficou conhecida como "higienismo". Com influência de uma nova abordagem médica europeia, sobretudo com base na escola francesa (assim como no urbanismo), tentava-se resolver problemas de saúde originados pela revolução industrial. Acreditava-se que o "meio é a origem da maior parte das doenças". ${ }^{18}$ Assim, estabeleceu-se um contraste entre o mundo natural e o urbano (rural/urbano, campo/cidade), propondo uma nova reflexão sobre essa dualidade. Para a escola francesa, a cidade era um ente patogênico que "produzia" doenças. ${ }^{19}$

\footnotetext{
${ }^{16}$ GODOY, Relatório sobre a conveniência da mudança da capital, p. 19.

${ }^{17}$ JANUZZI, Denise Cássia Rossetto, O desenvolvimento de Londrina e as transformações nos espaços públicos da região central, Semina: Ciências Sociais e Humanas, v. 26, p. 87-94, 2005.

${ }^{18}$ CHASLES, Virginie, "Saúde urbana e higienismo , o exemplo da França," Revista do Instituto de Estudos Brasileiros, n. 64, p. 65-74, 2016, p. 67.

${ }^{19}$ GONDRA, José, Artes de Civilizar: medicina, higiene e educação escolar na Corte Imperial, Rio de Janeiro: Ed. UERJ, 2004.
} 
Muito influenciado pelo higienismo médico, Pedro Ludovico, procurou estender essa filosofia para outros campos de atuação, o que ele chamou de nova política para Goiás. ${ }^{20} \mathrm{~A}$ influência do progressismo urbano pode ser destacada pelo convite feito ao arquiteto Attilio Corrêa Lima (1901-1943) para que este atuasse como o urbanista da nova capital de Goiás. ${ }^{21}$ Corrêa Lima havia concluído o curso de arquitetura pela Escola Nacional de Belas Artes no Rio de Janeiro em 1925, tendo feito, em seguida, curso de pós-graduação em urbanismo pelo Institut d'Urbanisme de l'Université de Paris, entre 1927 a $1930{ }^{22}$ Dentre as preocupações que orientavam a planificação urbana de Goiânia destacamos as questões relacionadas à localização do centro cívico e da malha urbana original da cidade, que deveriam estar posicionados em região de relevo menos inclinado, próximos a cursos d'água, facilitanto o abastecimento aos cidadãos e a coleta de esgotos. ${ }^{23}$ Outra preocupação era com as áreas verdes, entendidas como espaços privilegiados e que desempenhariam um papel importante para a qualidade de vida dos habitantes de Goiânia. ${ }^{24}$ Efetivamente, esses espaços - bastante valorizados pela arquitetura progressista a partir da primeira metade do século XIX - eram considerados fundamentais para a "moralização" das classes operárias e também como ambientes de convívio entre os cidadãos. Assim, não somente parques, mas também ruas ajardinadas e propícias ao passeio (como os boulevares), além de praças, eram concebidos pela visão progressista urbana como espaços culturais privilegiados. ${ }^{25}$

Essas características históricas, relacionadas às origens do projeto urbano de Goiânia, evidenciam variáveis relacionadas ao conceito de salubridade e o papel dos bens e dos espaços naturais para a concepção da cidade sonhada. ${ }^{26}$ E nessa perspectiva, Pesavento (2007) nos convoca a pensar o urbano para além da sua realidade física. Segundo essa historiadora, a cidade tem outra representação, ainda mais fascinante do que a realidade física dos seus espaços contruídos, organizados e ocupados. Para Pesavento, a experiência das cidades, portanto, se fundamentava em uma complexa rede de sociabilidades

\footnotetext{
${ }^{20}$ CAMPOS, 2002, op. cit.

${ }^{21}$ CHOAY, 2015, op. cit.

${ }^{22}$ DINIZ, Anamaria, “Goiânia: modernismo periférico”, Revista Estética e Semiótica, v. 7, n. 1, p. 101-114, 2017.

${ }^{23}$ CORRÊA LIMAa, Attilio, “Goiânia: a nova capital de Goiás”, Arquitetura e Urbanismo, p. 140-146, 1937.

${ }^{24}$ CORRÊA LIMAb, Attilio, “Goiânia: a nova capital de Goiás”, Arquitetura e Urbanismo, p. 60-63, 1937.

${ }^{25}$ CHOAY, Françoise, “A natureza urbanizada, a invenção dos “espaços verdes”, Projeto História, v. 18, p. 103-106, 1999.

${ }^{26}$ PESAVENTO, Sandra Jatahy, “Cidades visíveis, cidades sensíveis, cidades imaginárias”, Revista Brasileira de História, v. 27, n. 53, p. 11-23, 2007.
} 
e sensibildidades do fazer-se urbano. ${ }^{27}$ Isso porque a cidade abriga, além do aglomerado populacional, outras experiências, expressas nas mais diferentes representações do ethos urbano, seja nas práticas cotidianas, nos rituais e nos códigos de civilidade dos seus moradores. Para além das cidades reais, a autora destacava "outras tantas cidades imaginárias, a mostrar que o urbano é bem a obra máxima do homem, obra esta que ele não cessa de reconstruir, pelo pensamento e pela ação, criando outras tantas cidades, no pensamento e na ação, ao longo dos séculos". ${ }^{28}$

As cidades imaginárias possuem um papel importante em qualificar o mundo social, tornando-se representações concretas e reais das cidades vividas. Essa representação imaginária pode ser percebida como a força motora da ação humana, capaz de atribuir significados à realidade, podendo caracterizar-se em obras exequíveis e concretas, ou mesmo em utopias e visões urbanas jamais realizadas. Essas representações, que compõem a natureza peculiar das cidades, são fundamentais para a história urbana e os espaços outrora concebidos. ${ }^{29}$

Essas reflexões introdutórias se justificam na medida em que nos interessa conhecer o papel das áreas verdes em Goiânia, presentes no seu projeto inaugural e reconfiguradas na expansão da cidade sobre os espaços naturais. Uma importante consideração e que serviu de problematização para a elaboração dessa pesquisa refere-se aos discursos utilizadas nos ultimos anos nos quais relacionavam a qualidade de vida em Goiânia com a quantidade de áreas verdes por habitante. ${ }^{30}$ Os discursos do setor público utilizavam a imagem de Goiânia como a "Cidade Verde", fazendo referências aos índices da Organização Mundial de Saúde (OMS), que estabelecem métricas de área verde por habitante. Para Cavalheiro e Nucci (1998) esses dados precisam ser relativizados, e que a indicação de que os $12 \mathrm{~m}^{2}$ de área verde/habitante referem-se somente às categorias de parques de bairro e distritais/setoriais, ou seja, áreas públicas com possibilidades de lazer ao ar livre. ${ }^{31}$ Nesse sentido os discursos governamentais dão suporte aos projetos do setor imobiliário, em que o capital privado incorpora as áreas verdes públicas da capital goiana

\footnotetext{
${ }^{27}$ Ibidem

${ }^{28}$ Ibidem., p. 11

${ }^{29}$ PESAVENTO, 2007, op. cit.; Jacobs, Jane. Morte e vida de grandes cidades. São Paulo: Martins Fontes, 2000

${ }^{30}$ Prefeitura de Goiânia. Goiânia: Capital Verde do Brasil. https://www.goiania.go.gov.br/sobre-goiania/; Brasil. Ministério do Turismo. Goiânia: a cidade verde completa 81 anos. 21 de Outubro de 2014. http:// www.turismo.gov.br/\%C3\%BAltimas-not\%C3\%ADcias/708-goiania--a-cidade-verde-completa-81-anos.html ${ }^{31}$ CAVALHEIRO, F.; NUCCI, J.C. "Espaços livres e qualidade de vida urbana”. Paisagem Ambiente Ensaios, n.11, p. 279-288, 1998
} 
como possibilidades e potencialização lucrativas para o setor. Assim, as políticas públicas de criação e gestão das áreas verdes tem servido como capital simbólico ${ }^{32}$ para a promoção privada da produção de espaço e da organização territorial de Goiânia.

Em relação ao conceito de áreas verdes percebemos que essa é uma categoria controversa para a avaliação dos índices de cobertura vegetal nos espaços urbanos. ${ }^{33}$ No entanto, no que se refere ao conceito de áreas verdes urbanas, existe um certo concenso. Neste trabalho utilizamos o conceito de áreas verdes para a designar os diversos tipos de espaços urbanos, caracterizados por serem espaços públicos, abertos, acessíveis, relacionados ao bem estar, saúde e recreação da população. Esses espaços também se caracterizam pela interação das atividades humanas com o meio ambiente, podendo corresponder, em geral, a parques, jardins ou praças. ${ }^{34}$ Em relação a expansão urbana e as àreas verdes, estudos indicam um aumento da pressão sobre a capacidade de suporte ambiental das grandes cidades, sobretudo à supressão da sua cobertura vegetal e diminuição desses espaços..$^{35}$ Outro ponto importante tem sido a relação entre a valorização das áreas verdes pela especulação imobiliária, no qual os serviços de ecossistema cultural urbano, com maior cobertura vegetal, agregam valor à propriedade e têm sido um elemento de distinção para o mercado. ${ }^{36}$

Com base nesse contexto, esse trabalho tem como objetivo analisar as origens históricas da construção do espaço urbano de Goiânia e as transformações em relação aos diferentes usos das áreas verdes ao longo dos anos. Nossa intenção é dialogar com o projetos urbanisticos da cidade (sonhada e real), a qual vai se constituindo e se transformando ao longo dos anos. E nessa nossa investigação, muito nos interessa os diferentes usos e apropriações das áreas verdes e como a percepção histórica da cidade nos releva o papel da natureza nessa constituição urbana. E alguns questionamentos são fundamentais,

\footnotetext{
${ }^{32}$ BOURDIEU, Pierre, O poder simbólico. Rio de Janeiro: Bertrand Brasil, 1989. BOURDIEU, Pierre, A distinção: crítica social do julgamento. São Paulo: Edusp; Porto Alegre, RS: Zouk, 2008

${ }^{33}$ OLIVEIRA, Carlos Henke, Planejamento ambiental na cidade de São Carlos (SP) com ênfase nas áreas públicas e áreas verdes: diagnósticos e propostas, . Dissertação de Mestrado. Universidade Federal de São Carlos, 1996.

${ }^{34}$ DEMATTÊ, Maria Esmeralda Soares Payo, Princípios de paisagismo, Jaboticabal: Funep, 1997.

${ }^{35}$ AMATO-LOURENÇO, Luís Fernando et al, "Metrópoles, cobertura vegetal, áreas verdes e saúde”, Estudos Avançados, v. 30, n. 86, p. 113-130, 2016; COUTTS, Christopher; HAHN, Micah, "Green Infrastructure, Ecosystem Services, and Human Health", International Journal of Environmental Research and Public Health, v. 8, n. 12, p. 9768-9798, 2015; DONOVAN, Geoffrey H.; BUTRY, David T., "Trees in the city: Valuing street trees in Portland, Oregon", Landscape and Urban Planning, v. 94, n. 2, p. 77-83, 2010.

${ }^{36}$ ESCOBEDO, Francisco J.; ADAMS, Damian C.; TIMILSINA, Nilesh, "Urban forest structure effects on property value", Urban forest structure effects on property value, v. 12, p. 209-217, 2015.
} 
a saber: De que forma os diferentes discursos sobre as natureza e os seus espaços de cobertura vegetal aparecem como elemento impulsionador do desenvolvimento urbano em Goiás nas décadas de 1930 e 1940? Como eles espaços vão sendo apropriados ao longo dos anos no avanço da cidade sobre as áreas adjacentes? E de que forma as apropriações e expansão fundiária em Goiânia, entre as décadas de 1930 e 1940, podem nos ajudar a compreender as transformações urbanas sobre a vegetação original da cidade?

Procurando trabalhar com pressupostos teórico-metodológicos da história ambiental e história urbana, sobretudo com os estudos relacionados aos processos de urbanos e seu hinterland esse estudo utilizou-se de diferentes fontes de pesquisa, como publicações científicas, fotografias, plantas urbanas e outras documentações primárias relacionadas à criação da nova capital de Goiás. Aqui trabalhamos com o conceito de hinterland com base nos pressupostos geográficos e sociológicos do termo. Esse foi um conceito muito utilizado durante o Estado Novo (1937-1945) para caracterizar as políticas de ocupação do Brasil Central. O uso conceitual de hinterland estava associado a dois fenômenos distintos. Primeiro caracterizado na criação de zonas geográficas no interior nos pais, que receberiam focos de expansão demográfica e que estariam em conexão com o eixo econômico brasileiro, fundamentada numa relação de interdependência. A segunda, caracterizada na interação entre os espaços rurais e urbanos, criando zonas econômicas que favoreciam uma relação de interdependência entre a cidade e as áreas periféricas, criando também outro hinterland. Apropriamo-nos dessas categorias na interpretação do projeto urbano para Goiânia, em processos nacionais e regionais. Sobre os diferentes usos do conceito de hinterland. ${ }^{37}$ Também, foram utilizadas imagens cartográficas, identificando a mudança das edificações após a implantação e urbanização das áreas verdes. Desta forma, tenta-se identificar o papel da natureza como promotora de desenvolvimento econômico, contrastando com elementos naturais degradados como, especialmente, os recursos hídricos de Goiânia.

\section{As áreas verdes, o hinterland e a cidade sonhada}

O primeiro esboço criado para projeto urbano de Goiânia levava em consideração as características ambientais da região escolhida para sediar a nova capital. Em 1932, Correia Lima havia feito uma pesquisa de campo na

${ }^{37}$ CRONON, 1991, op. cit..; JONES, Lewis W. “The Hinterland Reconsidered”, American Sociological Review, Vol. 20, No. 1 (Feb., 1955), pp. 40-44 
região de Campinas, que recebeu no mesmo ano, a indicação para sediar a nova capital de Goiás. ${ }^{38}$ Em dezembro do mesmo ano ocorreu a publicação da decisão da subcomissão, mas Corrêa Lima já havia já desenhado um primeiro esboço do traçado urbano de Goiânia (figura 1), justamente para a região de Campinas.$^{39}$ Nesse esboço, ele apresentava as características físicas da cidade sonhada, dialogando com as áreas verdes adjacentes. Além do planejamento, a metrópole do hinterland estava localizada em uma zona de transição ecológica, com diferentes composições florísticas das paisagens do Cerrado. Esse mosaico de fitofisionomias nos ajuda a compreender as apropriações paisagística como parte da história ambiental e urbana do Cerrado. ${ }^{40}$

Em termos de composição florística a região escolhida para sediar a nova capital era caracterizada como uma formação campestre, com formações florestais ciliares, formada pelos capões que margeavam os córregos Botafogo, Buritis e Capim-puba. Além destes, destacamos uma formação de veredas e capões de buritis. Essa formação de capões ciliares aparece no esboço de 1932, mas sem nenhuma designação paisagista ou funcional aparente. No entanto, na planta urbana publicada em 1937, Corrêa Lima demarca uma área de parque para o bosque de buritizal e agrega as demais áreas verdes, sem uma definição clara destas, como veremos mais adiante (figura 3).

A descrição desse mosaico florístico e as peculiaridades naturais que compõe a área escolhida para a nova capital de Goiás, são elementos importantes para a reflexão sobre a cidade real e imaginada. ${ }^{41}$ A região escolhida estava localizada em uma área de campo cerrado, utilizada na época como uma fazenda para o pastoreio de gado, próxima ao antigo vilarejo de Campinas. A origem do termo "campinas" advém da etimologia de campo, que é uma variação paisagística dos cerrados. Essa paisagem campestre caracteriza-se por sua composição vegetal de gramíneas e herbáceas, com pouca vegetação

\footnotetext{
${ }^{38}$ SABINO JUNIOR, 1960, op. cit.; MENDONÇA, Jales Guedes Coelho, "A queda de bonfim e a escolha prévia de campinas", Mosaico, p. 175-189, 2009. Embora o decreto que estabelecia a escolha do local tenha sido publicado em 20 de dezembro de 1932, há documentos que comprovam a atuação de Attilio Corrêa Lima antes de sua promulgação.

${ }^{39}$ DINIZ, 2017, op. cit.; DUTRA E SILVA; DUTRA E SILVA, 2019, op. cit.

${ }^{40}$ Sobre a história ambiental do Cerrado e sua diversidade paisagística ver: DUTRA E SILVA, S. "Challenging the Environmental History of the Cerrado: Science, Biodiversity and Politics on the Brazilian Agricultural Frontier". Historia Ambiental Latinoamericana Y Caribeña (HALAC) Revista De La Solcha, 10(1), 82116, 2020, disponível em: https://doi.org/10.32991/2237-2717.2020v10i1.p82-116; DUTRA E SILVA, S., BARBOSA, A. S. "Paisagens e fronteiras do Cerrado: ciência, biodiversidade e expansão agrícola nos chapadões centrais do Brasil”. Estudos Ibero-Americanos, 46(1), e34028, 2020, disponível em: https://doi. org/10.15448/1980-864X.2020.1.34028.

${ }^{41}$ PESAVENTO, 2007, op. cit.
} 
arbórea, e que se manifesta geralmente em terrenos pouco acidentados, como as planícies e planaltos. Essa característica favorecia a topografia urbana da nova capital e a planificação de seu traçado urbano, além dos recursos hídricos abundantes para o abastecimento de água. Outra representação, mencionada anteriormente, são os capões ciliares, composto tanto por formação florestal como por veredas de buritis e que reforçam a riqueza hídrica do ambiente.

Figura 1 - Esboço da locação do centro urbano feito por Attilio Correa Lima em 1932.

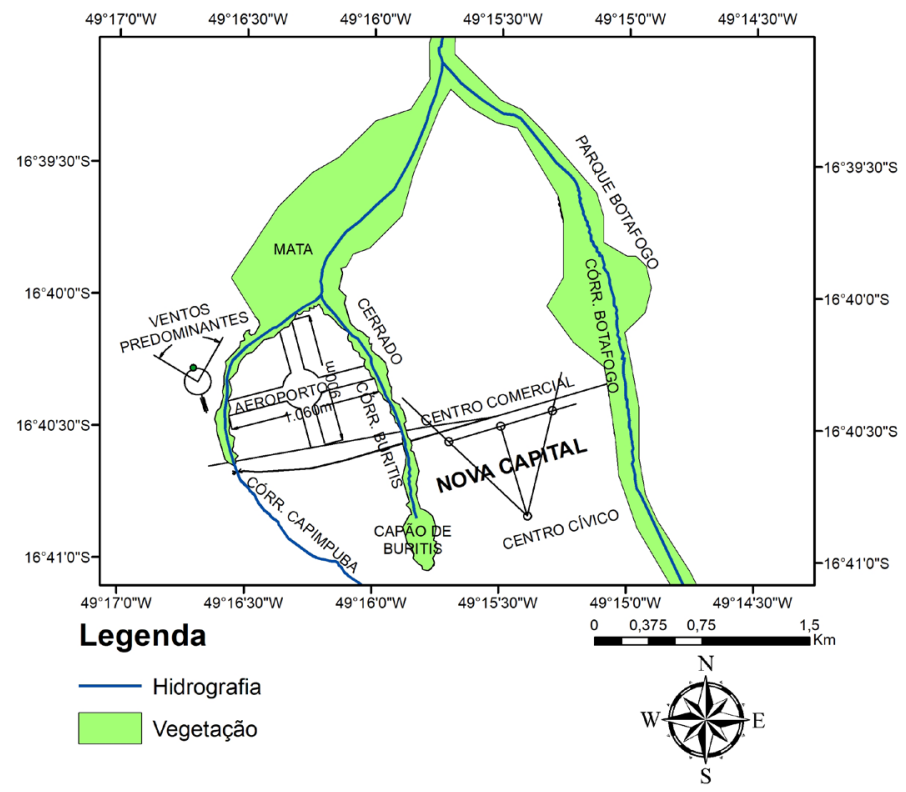

Fonte: Essa figura foi elaborada a partir de documentação coletada pela pesquisadora Anamaria Diniz (2017) $)^{42}$ - adaptado pelos autores.

Além dessas características mais específicas do plano urbano de Goiânia, destacamos que o sítio da cidade estava localizado às bordas de uma grande floresta tropical, conhecida na época como Mato Grosso de Goiás ${ }^{43}$ e que passaria a compor o grande hinterland ${ }^{44}$ da nova capital. Essa região experimentava

\footnotetext{
${ }^{42}$ DINIZ, 2017, op. cit.

${ }^{43}$ DUTRA E SILVA, 2017, op. cit.; DUTRA E SILVA; DUTRA E SILVA, 2019, op. cit.

${ }^{44} \mathrm{~A}$ principal referência em história ambiental para o uso do conceito de hinterland é a obra de William Cronon (1991), no qual o autor faz uma importante análise da cidade de Chicago e a relação com o mundo rural que compunha o seu entorno. Nesse sentido, o uso histórico de hinterland se fundamenta na relação entre cidade/campo e urbano/rural, numa composição de interdependência entre os recursos naturais e
} 
um grande avanço demográfico por meio da política da Marcha para o Oeste, criada em um 31 de dezembro de 1937, e implementada a partir de 1938, no qual o governo favorecia a migração interna na expansão da fronteira agrícola. Além disso, uma ferrovia estava em construção e que tinha como destino final a cidade de Anápolis, também às bordas do Mato Grosso de Goiás. Anápolis se localizava a uma distância de 50 quilômetros à nordeste de Goiânia, e experimentava um crescente boom demográfico e econômico, fator esse que facilitaria a configuração desse importante hinterland. ${ }^{45}$

Attilio Corrêa Lima, além de ser responsável pelo traçado urbano de Goiânia, tinha também a responsabilidade de projetar os edifícios públicos principais e as casas de funcinários. A área foi demarcada pela subcomissão, por força política do governador, que utilizou, dentre as prerrogativas da escolha, as questões relacionadas aos recursos naturais e as potencialidades e facilidades da criação do seu hinterland, cujos processos de expansão demográficas para as areas rurais da grande floresta tropical estava em andamento. Assim, resumidamente, os fatores envolvendo os benifícios ecologicos, geográficos e sociologicos e que justificativam o sucesso da empreitada para a região de Campinas podem ser assim descritos: a proximidade ao Mato Grosso de Goiás e à estrada de ferro (apesar de que era acessada por rodovias de terra), a topografia pouco acentuada e os generosos cursos d'água e formações florestais. ${ }^{46}$

Em relação às questões ambientais e sanitárias, a comparação com a antiga capital reforça o papel dos discursos progressistas e sanitaristas utilizados para justificar a escolha da área que receberia a nova capital. As carências ambientais da antiga capital eram destacadas, como forma de evidenciar a abundância desses recursos na região que abrigava a nova capital. Por exemplo, em publicações feitas em 1937 na revista Arquitetura e Urbanismo, ${ }^{47} \mathrm{O}$ arquiteto Correia Lima expunha as condições precárias do abastecimento de água e as questões consideradas fundamentais para a salubridade da população. E o arquiteto reforçava que no século XIX, Couto de Magalhaes, então governador da Província de Goiás, reclamava das precariedades sanitárias da antiga capital, e que, no século XX essas reclamações eram reforçadas por Pedro Ludovico em relatórios escritos a Getúlio Vargas entre os anos de 1930

\footnotetext{
os processos de apropriação destes pelo espaço urbana e vice-versa.

${ }^{45}$ DUTRA e SILVA, Sandro; BELL, Stephen. "Colonização agrária no Brasil Central: fontes inéditas sobre as pesquisas de campo de Henry Bruman em Goiás, na década de 1950”. Topoi (Rio J.) [online], vol.19, n.37, pp.198-225, 2018. ISSN 2237-101X. http://dx.doi.org/10.1590/2237-101x01903709.

${ }^{46}$ MENDONÇA, 2009, op. cit.; MENDONÇA, Jales Guedes Coelho, O Outro Lado da Mudança da Capital de Goiás. Tese de Doutorado, Faculdade de História, UFG, Goiânia, 2012; SABINO JUNIOR, 1960, op. cit.

${ }^{47}$ CORRÊA LIMAb, 1937, op. cit.
} 
a $1932 .{ }^{48}$ Segundo Corrêa Lima, o abastecimento de água na antiga capital se fazia por dois chafarizes no centro da cidade. No período de estiagem, no entanto, essas fontes praticamente se esgotavam. $\mathrm{O}$ arquiteto afirma ainda que o esgoto urbano era depositado em covas feitas em solo rochoso, de difícil perfuração para instalação de tubulações. A antiga capital tinha, também ao seu desfavor um relevo muito acidentado, dificultando a boa circulação de automóveis nos períodos chuvosos. ${ }^{49}$

Como norteadores de projeto urbanístico da cidade de Goiânia, Corrêa Lima estabeleceu três pontos principais: a integração da rodovia que ligava o ponto mais próximo da estrada de ferro a Campinas, o terreno com menor inclinação e a distância do reservatório de abastecimento, destinado à região que era conhecida como "Paineira".${ }^{50}$ Esta configuração posicionava a malha da capital no espaço compreendido entre os córregos Botafogo e Capim-puba. Se a forma de triângulo (o centro cívico e comercial na figura 1), herdada do urbanismo francês que o influenciara, visava convergir as principais vias ao Centro Cívico, ${ }^{51} \mathrm{em}$ sentido oposto, elas, divergindo entre si, iriam até o encontro dos regatos. Se imaginarmos um crescimento demográfico tendo como ponto de partida o vértice desse triângulo para sua base, é fácil pensar que o seu caminho mais "natural" e "espontâneo" seria a continuidade das vias em direção às matas ciliares e aos cursos d'água. E, também, a forma em "cruz" de duas pistas de pouso compreendidas entre os córregos Buriti e Capim-puba causam um certo desconforto, seja pela desproporção em relação à malha urbana (embora as pistas estejam representadas em escala correta), ou por estarem em um limite delicado entre o que seria construído e o que deveria ser mantido intacto (o aeroporto na figura 1).

Esse esboço, que se apresenta como a cidade sonhada e o primeiro elemento norteador do projeto final da planificação urbana de Goiânia, demonstra não só o reconhecimento da paisagem natural existente, como também a percepão por parte do urbanista para os usos e aproveitamento dos seus recursos naturais. As indicações "capão de buritis", "cerrado" e "mata" destacam tais elementos como pontos importantes, não só como referências de local, mas como fatores determinantes do projeto. Eles elementos naturais deveriam estar integrados ao traçado urbano, conforme indica o esboço da

\footnotetext{
${ }^{48}$ GODINHO, Iúri Rincon, O estudo que construiu Goiânia, Goiânia: Contato Comunicação, 2018.

${ }^{49}$ CORRÊA LIMAc, Attilio, “Goiânia: a nova capital de Goiás”, Arquitetura e Urbanismo, p. 32-34, 1937.

${ }^{50}$ Ibidem.

${ }^{51}$ BRUAND, 1997, op. cit.; DINIZ, 2017, op. cit.; DAHER, Tânia, “O Projeto Original de Goiânia”, Revista UFG, v. 11, n. 6, p. 77-91, 2009; MANSO, 2001, op. cit.
} 
figura 1. Um destaque fundamental é para o uso urbano da áreas relacionadas ao capão de buritis, e as matas ciliares do Capim-puba e do córrego do Botafogo, que eram áreas verdes que passariam a componto parques e bosques no projeto original de Goiânia, como descrito no trecho adiante:

O buritizal, situado entre as ruas " 72 " e alameda dos Buritis, será transformado em pequeno parque. É necessário drená-lo convenientemente, conduzindo as águas pelo talweg, em canal descoberto, tirando partido deste para os efeitos de cascata e um grande lago recreativo. (...) O córrego Botafogo, a partir do açude onde serão represadas as águas para o abastecimento da cidade, será tratado como park-way numa faixa nunca inferior a 50 metros para cada lado, a contar do leito do rio, e terminará no bosque Botafogo. ${ }^{52}$

Esses dados são relevantes, pois esclarecem a intensão do urbanista em aproveitar essas paisagens naturais e dar outros significados a elas, na integração com a nova paisagem urbana em construção. Corrêa Lima, mais do que explorar as águas para o abastecimento, desejava criar corredores verdes (parkways) para a integração da cidade nas margens leste e oeste dos córregos adjacentes à malha urbana. Dessa forma, tanto os córregoss Capimpuba quanto o Botafogo teriam generosas faixas de vegetação às margens de seus cursos d'água, e com a preservação da áreas verde decorrente da junçãos destes, compondo o bosque Botafogo. Conforme os indícios documentais de Corrêa Lima o bosque Botafogo seria o principal parque da cidade, com uma área estimada em 54 hectares composta por uma "vegetação luxuriante onde medram espécies frondosas das nossas madeiras de lei". ${ }^{53}$ Esse bosque teria uma função importante, tanto no projeto de circulação dos cursos d'água, quanto na mobilidade e composição paisagística da nova capital, por meio dos parkways.

O projeto goiano dos parkways ${ }^{54}$ - uma influência da arquitetura paisagística de Frederick Law Olmsted (1822-1903) - deve ser compreendido para além do seu conteúdo estético de valorização da paisagem urbana. $\mathrm{Na}$ verdade a arquitetura paisagística é um legado desse projeto funcional, no qual o lazer e recreação tinham finalidades secundárias, apesar de ser essa a visão mais conhecida. O projeto dos parkways funcionava como um sistema para drenagem e controle das cheias, conservação da qualidade dos cursos

\footnotetext{
${ }^{52}$ CORRÊA LIMAa, 1937, op. cit., p. 145.

${ }^{53}$ CORREAA LIMAa, 1937, op. cit.

${ }^{54}$ SPIRN, Anne Whiston, O jardim de granito, São Paulo: Edusp, 1995.
} 
d'águas, e no caso mais específico de Olmsted, para combater os problemas relacionados às enchentes e a poluição das várzeas da Back Bay de Boston. ${ }^{55}$

A inclusão dessas áreas verdes nos projeto paisagístico cumpria também outras finalidades ecológicas, conhecidas também como greenways, ${ }^{56}$ os quais eram corredores naturais que margeavam os córregos, ribeiros, cursos de água, canais, e mesmo linhas férreas e rodovias. Funcionavam como rotas e caminhos de integração entre as áreas verdes. Além das funcionalidades, geralmente associadas aos recursos hídricos, assumiam outras finalidades no traçado urbano, por suas funções ecológicas e sociais (lazer e recreação). Para Norman Newton os greenways se caracterizam como um sistema de parques e áreas verdes em benefício das vias públicas. ${ }^{57}$

Importante destacar que o projeto original de parways para Goiânia visava a integração desses espaços de circulação hídrica e também do fluxo logístico na capital e que, ao mesmo tempo, funcionava na integração geográfica, compondo em sua junção o bosque Botafogo (o qual deveria ser transformado em parque segundo Corrêa Lima). Uma fotografia de 1937 (figura 2) nos ajuda a compreender a função estética do bosque Botafogo na composição da paisagem urbana em Goiânia no período da construção da nova capital. A imagem evidencia as primeiras construções na região central da capital, e tendo a fundo, a esquerda, um panorama do bosque Botafogo. A imagem também nos permite identificar que não se trata de um bosque típico de cerradão, mas definido como "mata", que era o conceito característico usado na época para formações de florestas tropicais. Também, no registro de Corrêa Lima percebemos a referência a madeira de lei, o que evidencia a presença de espécies típicas de floresta tropical, muito presente no Mato Grosso de Goiás. Outro elemento importante na compreensão das áreas verdes e seu papel na cidade sonhada - e cujo registro do arquiteto traz elementos simbólicos ricos nessa descrição - era que esse não deveria ser concebido como um lugar efêmero, mas um patrimônio paisagístico a ser mantido para a posteridade. ${ }^{58}$

\footnotetext{
${ }^{55}$ FABOS, Julius Gy.; RYAN, Robert L., "Greenway planning in the United States: its origins and recent case studies", Landscape and Urban Planning, v. 68, n. 2-3, p. 305-319, 2004; OLMSTED, Frederick Law, Olmsted: writings on landscape, culture, and society, New York: The Library of America, 2015.

${ }^{56}$ AHERN, Jack, "Greenways as a planning strategy", Landscape and Urban Planning, v. 33, n. 1-3, p. 131-155, 1995; BASCHAK, Lawrence A.; BROWN, Robert D., "An ecological framework for the planning, design and management of urban river greenways", Landscape and Urban Planning, v. 33, n. 1-3, p. 211-225, 1995; LITTLE, Charles E., Greenways for America, Baltimore: John Hopkins University Press, 1990.

${ }^{57}$ NEWTON, Norman T., Design on the Land, Cambridge: The Harvard University Press, 1971.

${ }^{58}$ Para essa reflexão importante considerar as assertivas do historiador ambiental Mark Stoll sobre o papel das áreas verdes urbanas nas origens do movimento ambiental norte-americano. Nessa análise o legado de Olmsted é indicado como um exemplo de reprodução dos valores ambientais da Nova Inglaterra, na
} 
Figura 2 - Trecho da av. Anhanguera com parte do bosque Botafogo ao fundo em 1937.

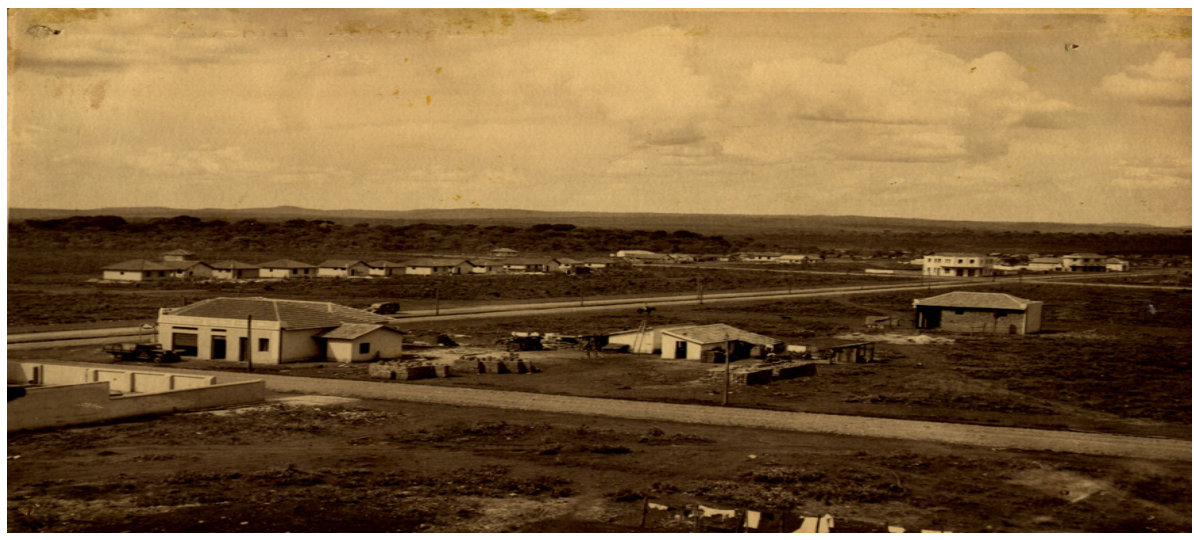

Fonte: autor desconhecido (1937). Cortesia: Acervo MIS/GO.

Sobre as matas ciliares o projeto indica que tais margens deveriam ser demarcadas e cercadas, impedindo qualquer uso, mesmo o agrícola. Corrêa Lima definiu ainda que, ao longo dos córregos fossem criadas cascatas e outros elementos de integração com a natureza. Também previa a construção de uma barragem abaixo da confluência do córrego Botafogo com o córrego Areião (a sudeste do Centro Cívico) para servir de manancial de abastecimento público de água.

O urbanista reforçou a ideia de que as áreas verdes eram elementos essenciais para a qualidade do ar das grandes cidades. Corrêa Lima procurou também valorizar as características ambientais do seu projeto, considerando que as áreas verdes - chamadas por ele também de "áreas vazias" - equivaliam a 34,6\% de toda a extensão do projeto urbano. A partir dessa documentação podemos perceber uma defesa para o uso e manutenção das matas como elementos de composição de praças e jardins, chegando a fazer um dimensionamento de 308 habitantes por hectare de parque, o que representava,

medida em que o arquiteto e paisagista creditava aos parques urbanos a capacidade de despertar no cidadão um espírito de quietude e contemplação, que teria a função condicionante de reverência e respeito aos bens naturais. Segundo essa concepção, as áreas verdes funcionariam como espaços de moralização - tanto para a paisagem urbana quanto para os seus cidadãos - frente ao crescimento populacional e os processos industrialização. Ver: STOLL, Mark, Inherit the Holy Moutain - Religion and the Rise of American Environmentalism, New York: Oxford, 2015. 
por exemplo, o dobro de área verde per capita do que a cidade de Detroit, nos Estados Unidos e por volta de quatro vezes mais que a cidade de Paris.59

Uma outra preocupação que Corrêa Lima demonstrava em seu projeto era com o surgimento de novos loteamentos e o crescimento desordenado da cidade, em especial, para além do córrego Botafogo (a leste da capital). Mesmo ciente desta importância, não se compromete em defender a regulamentação desses espaços, delegando ao poder público a demarcação das matas e parques, indicando que isto se daria somente nos anos seguintes..$^{60} \mathrm{Como}$ o seu contrato com o governo de Goiás foi rescindido em 1935, Correia Lima não interferiu na gestão das obras, ${ }^{61}$ permitindo que o poder público e a iniciativa privada fizessem uso de partes dessas áreas. O resultado foi uma ocupação desordenada dessas áreas verdes, comprometendo o projeto original de Corrêa Lima.

Em sua origem, o projeto de Goiânia tirava partido dos bosques e dos recursos hídricos existentes, seja pela composição da paisagem, seja por sua função utilitária, como a qualidade do ar, o abastecimento e a produção de eletricidade. Visava ainda, a criação de vias amplas e ajardinadas, ajustadas ao automóvel e agradáveis aos pedestres. Essa um projeto ousado na época, se considerarmos que o modelo urbano das antigas cidades do Brasil Central se baseava em construções justapostas que acompanhavam a sinuosidade das ruas nas cidades de tradição colonial portuguesa (como a cidade de Goiás). Assim, esse projeto incluía como inovação o surgimento de vias amplas e “espaços vazios" generosos, interrompidos por bosques e matas ciliares.

No entanto, na medida em que o poder público associado aos interesses políticos e setores da iniciativa privada começaram a intervir na ocupação fundiária na capital ocorreu uma desconfiguração em muito desses espaços, com prejuízo para as áreas verdes previstas no projeto original. Por exemplo, o não detalhamento dos parkways permitiu que construções ocupassem as faixas mínimas de 50 metros ao longo dos córregos. O "Capão de Buritis" de fato foi apropriado como área verde pública para à criação do parque "Bosque dos Buritis". Porém, algumas intervenções mais radicais ocorreram, como por exemplo, a canalização do córrego sob as vias e construções da cidade. No mapa urbano de Goiânia, publicado em 1937 podemos ver como o traçado da cidade ocorreu, promovendo a fragmentação das áreas verdes (ver figura 3).

Apesar de considerar os espaços de vegetação florestal nativas no seu projeto original, a relação entre as áreas verdes e a expansão imobiliária na

\footnotetext{
${ }^{59}$ CORRÊA LIMAa, 1937, op. cit.

${ }^{60}$ Ibidem.

${ }^{61}$ ALVARES, 1942, op. cit.; SABINO JUNIOR, 1960, op. cit.
} 
capital foi muitas vezes conflituosa. Os desejos desenvolvimentistas estavam associados aos intereses de expansão do hinterland como também a conexão com o eixo econômico do Brasil. Assim, havia um desejo político na expansão urbana da cidade, e por outro lado, a preocupação com o crescimento desordenado. Os arredores, ainda pouco ocupados, seriam um campo fértil para a exploração imobiliária. Em 1937, o engenheiro Armando de Godoy (1876-1944), que substituiu Corrêa Lima nos trabalhos urbanisticos de Goiânia, registrou a sua preocupação com o crescimento desordenado em detrimento do planejamento prévio para o adensamento populacional e a abertura de novas áreas urbanas na periferia da nova capital. Godoy, citava como exemplo a capital mineira, que também havia sido fruto de um projeto de planificação urbana. Segundo ele, Belo Horizonte já apresentava fortes indícios de deturpação do seu plano urbano inicial, justamente por não prever restrições aos interesses privados especulativos. O engenheiro enaltecia o projeto do núcleo urbano de Goiânia, no entanto advertia para os aquisições imobiliárias de particulares que haviam adquirido propriedades rurais no entorno da capital. Esses especuladores passaram a "retalhar" esses terrenos em loteamentos aleatórios que acabavam por comprometer o conjunto urbanistico, gerando, segundo ele "quase a perda completa do valor do plano inicial". ${ }^{62}$

Assim, não apenas em relação à manutenção das áreas de cobertura vegetal, mas principalmente em relação ao hinterland, Armando de Godoy considerava que o papel do Estado seria fundamental no controle da expansão desordenada da malha urbana de Goiânia. Para o arquiteto era quase "impossível a execução do atual plano de [urbanização], se o Estado vender terras em torno da cidade. Caso isto se dê, cada proprietário irá fazer loteamento em sua gleba, guiados pelos interesses de lucro, sem obedecerem à menor preocupação de um plano. ${ }^{63}$

Apesar da defesa e advertência de Godoy, a questão dos investimentos urbanos era um problema para a administração pública da nova cidade, cujos recursos estavam escassos. Assim, o que acabou ocorrendo foi a transferência de áreas públicas ao setor privado como forma de recomposição de capital. Na medida em que o Estado passou a não dispor de recursos financeiros para pagar os fornecedores e outros credores, utilou a transferência de lotes urbanos públicos ao setor privado, como forma de garantir o crédito. Desse forma,

${ }^{62}$ GODOY, 1942, op. cit.

${ }^{63}$ Ibidem. 
acabou por abrir precedentes para a especulação imobiliária e a transformação da paisagem urbana em relação ao projeto original de Goiânia. ${ }^{64}$

Figura 3 - Mapa do traçado urbano de Goiânia por Attlilio Corrêa Lima (1937).

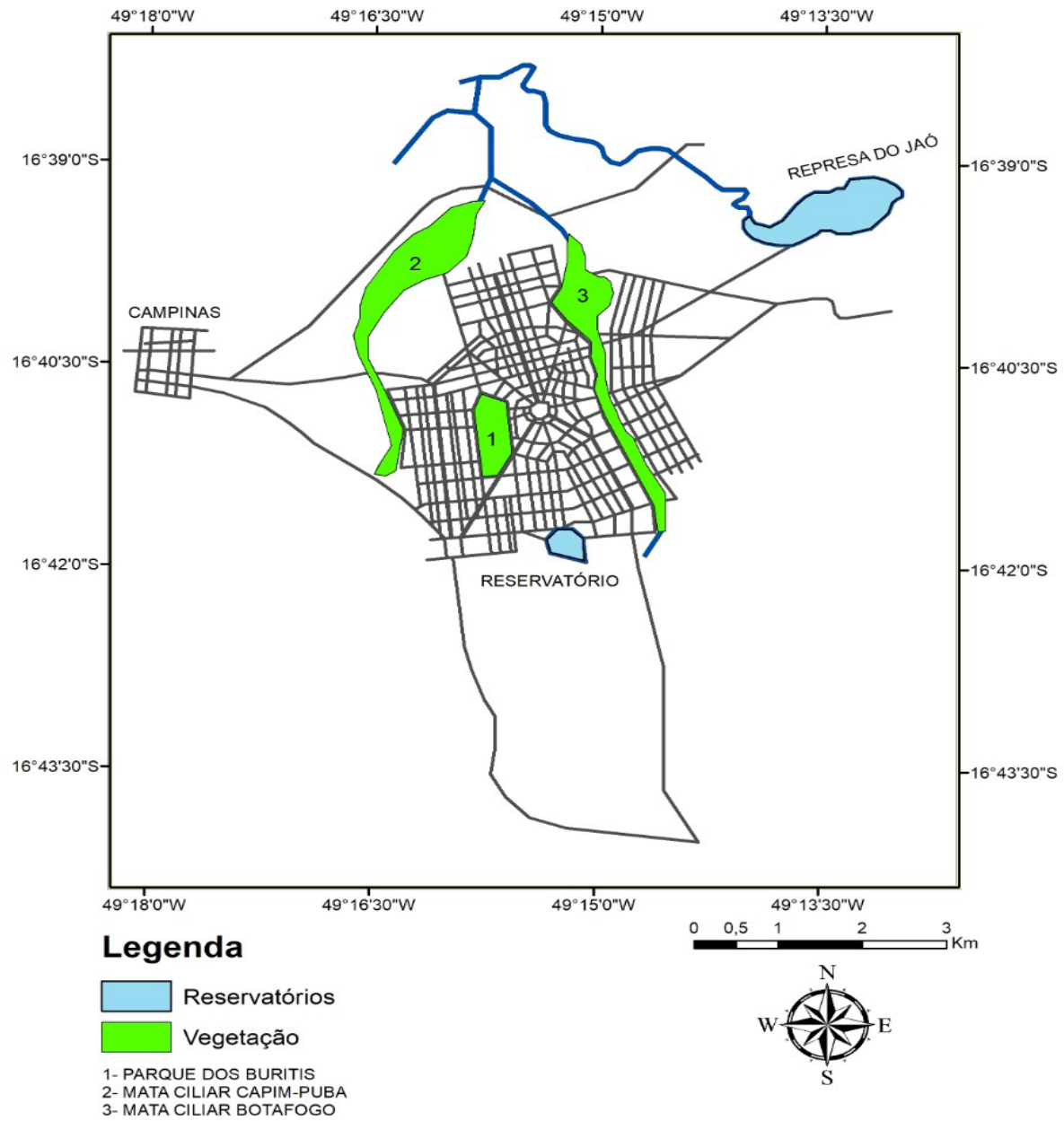

Fonte: Corrêa Lima (1937) - adptado pelos autores.

Estas duas realidades, planejamento e oportunismo, duelavam entre si pelo destino da metrópole sonhada e vivida. Corrêa Lima e Armando de Godoy,

${ }^{64}$ SABINO JUNIOR, 1960, op. cit. 
cuja formação técnica lhes dotara de recursos que poderiam ser aplicados para o bom planejamento urbano, acabaram sendo substituídos pelos engenheiros Jerônymo e Abelardo Coimbra Bueno (os irmãos Coimbra Bueno). ${ }^{65} \mathrm{O}$ governador Pedro Ludovico deu os irmãos Coimbra Bueno autonomia sobre toda a administração da construção de Goiânia, além de encarregá-los pela aquisição de recursos, uma vez que o estado não dispunha destes.$^{66} \mathrm{~A}$ comercialização de lotes também acabou recaindo sobre os empreiteiros, criando, assim, uma nova perspectiva sobre as relações econômicas, a necessidade de ampliar os projetos de construção civil visando o rápido crescimento e expansão fundiária. Dessa forma, os proprietários de terras e empreendedores, ao toque de suas necessidades econômicas, criaram loteamentos desconexos e de traçados variados, sem que houvesse qualquer ordem ou uniformidade, ${ }^{67}$ contrariando as recomendações dos urbanistas que antecederam aos irmãos Coimbra Bueno.

A respeito das áreas verdes, logo no início da ocupação de Goiânia, algumas ações acabaram sendo determinantes para a reconfiguração do projeto original. No caso do Bosque dos Buritis, a área definida como parque urbano por Attilio Corrêa Lima - e importante para a sua concepção de cidade higiênica - teve partes de seu território destinado para a criação de duas escolas (Externato São José e Ateneu Dom Bosco). Já no final da década de 1950 duas outras intervenções no Bosque dos Buritis ocorreram, reconfigurando, novamente, os espaços dessa área verde. Foi construído o Abrigo dos Velhos, que nos anos de 1980 foi transformado em museu e escola de artes. Também foi construído o edifício que passou a ser a sede da Assembleia Legislativa de Goiás, concluído no ano de 1962. Essas quatro intervenções arquitetônicas dentre outras construções em áreas do parque, e que permanecem até hoje - acabaram por reduzir o território previsto no projeto, diminuindo a área verde de veredas e capões de buritis. ${ }^{68}$

\section{o parcelamento do solo e a reconfiguração das áreas verdes em Goiânia}

De forma semelhante, a área florestada onde estava localizada a nascente do córrego Capim-puba - um curso hídrico fundamental para os interesses

\footnotetext{
${ }^{65}$ Ibidem.; DINIZ, Anamaria, Goiânia de Attilio Corrêa Lima (1932-1935): Ideal estético e realidade política. Dissertação de Mestrado, Faculdade de Arquitetura e Urbanismo, UNB, 2007.

${ }^{66}$ ALVARES, 1942, op. cit.

${ }^{67}$ BRUAND, 1997, op. cit.

${ }^{68}$ CAU-GO, Relatório dos Parques Urbanos de Goiânia, Goiânia: [s.n.], 2013.
} 
de abastecimento no projeto original - foi também transformada e reconfigurada a partir da expansão urbana dos anos de 1940 e 1950. No ano de 1937, a mata existente na região foi transformada em Horto Florestal, por influência dos profissionais que administravam o Jardim Botânico do Rio de Janeiro. ${ }^{69}$ Pelo Decreto $\mathrm{n}^{\circ}$ 90-A, de 30 de julho de 1938, foi aprovado o Plano de Urbanização de Goiânia, no qual estabelecia o projeto o aproveitamento das áreas verdes das nascentes do Capim-puba para a criação de um parque com um balneário. ${ }^{70}$

Em 1941, nas proximidades da avenida que ligava o centro de Goiânia à Campinas (que passou a ser um bairro da nova capital), foi construído um balneário para recreação e lazer da comunidade local. Essa área verde passou a ser chamada de Lago das Rosas. Conforme uma documentação de 1940 (um relatório sobre o ensino secundário em Goiás, apresentado pela Diretoria Geral de Educação ao Interventor Pedro Ludovico), o projeto paisagístico do Lago das Rosas estava inserido em um contexto educacional. A Diretoria exaltava a construção de uma "piscina" no Lago das Rosas, contextualizando os investimentos do governo estadual para a prática da educação física no ensino secundário em Goiânia. Dentre as obras em conclusão, o relatório indicava, ainda, a finalização do complexo esportivo "Estádio Pedro Ludovico", que abrigaria um campo de futebol, quadras desportivas e um centro aquático, cuja estrutura seria também destinada ao ensino secundário. Sobre o Lago das Rosas o relatório afirmava que estava quase concluída "a magnifica piscina do Lago das Rosas", destacando a sua localização nas proximidades do "Automovel Clube de Goiaz", e que passaria a ser uma área de valorização imobiliária para as classes mais abastadas da capital. ${ }^{71}$ Antes do projeto dos irmãos Coimbra Bueno de 1947, a maior parte dos espaços destinados originalmente para compor as áreas verdes de Goiânia não estava efetivamente assegurada. E em especial, para o Lago das Rosas e o Zoológico. Assim, as intervenções feitas pelos irmãos Coimbra Bueno, como a construção da Avenida Anhanguera e as obras do balneário, acabaram incorporando as áreas verdes do Horto Florestal, que passaram a compor esse novo parque urbano em Goiânia. ${ }^{72} \mathrm{E}$,

\footnotetext{
${ }^{69}$ Ibidem.

${ }^{70}$ Goiânia 1938. Decreto-Lei 90-A de 30 de julho de 1938. Sistema de Informação Geográfica de Goiânia Docs; Movimento Goiânia Memória Futura Memória. Goiânia art déco: acervo arquitetônico e urbanístico. Dossiê de tombamento. Bens de excepcional valor histórico e cultural. Pedido de tombamento federal. Goiânia, Goiás, setembro de 2002.

${ }^{71}$ Revista de Educação. Órgão da Diretoria Geral de Educação. Ano V n. 13, (novembro e dezembro de 1940). Tipografia Popular, Goiânia, 1941, p. 37.

${ }^{72}$ OLIVEIRA, H. A. DE; BEKER, S. S.; DOMINGOS, J. M. Goiânia-GO: Um Projeto de Cidade-Jardim que não
} 
logicamente, essa composição tinha um interesse muito mais especulativo do que propriamente em garantir a conservação dos recursos naturais.

Desde 1939, sobretudo a partir do Decreto 90-A, foram estabelecidas as diretrizes urbanas, suburbanas, particulares e públicas, bem como a delimitação das áreas verdes do plano urbanístico de Goiânia. ${ }^{73} \mathrm{~A}$ área verde que deu origem ao Lago das Rosas inicialmente estava destinada para a preservação das nascentes do córrego Capim-puba e recebeu outra designação, a partir da criação dos reservatórios (lagos) - chamados de piscinas pelo relatório da Diretoria de Educação -, agora com a finalidade de espaço para a recreação da população. E a região passou a ser o novo referencial para a expansão imobiliária da cidade, sobretudo a partir do momento em que a empresa Coimbra Bueno \& Cia. Ltda passou a administrar a política fundiária e imobiliária de Goiânia. Assim a década de 1940 marca a forte presença dos irmãos Coimbra Bueno no planejamento e operacionalização da expansão da malha urbana da cidade. Enquanto os projetos urbanos de Goiânia na década de 1930 tinham a intensão de preservar e manter a qualidade do solo urbano, com um percentual importante de "espaços vazios", com a grande presença de áreas verdes entre quarteirões e loteamento, o projeto dos irmãos Coimbra Bueno tinha, marcadamente, interesses evidentes em "demarcar territorialmente a cidade por meio de lotes com reais valores imobiliários e rentáveis do ponto de vista econômico". ${ }^{74} \mathrm{O}$ que destacava na expansão urbana promovida pelos irmãos Coimbra Bueno era a ampliação fundiária, ocorrida, principalmente, na interligação entre o polo-pioneiro, que era a localidade de Campinas (a partir de então incorporada como um bairro da capital), com o centro da cidade, tendo o Lago das Rosas como uma nova referência para a expansão imobiliária. Assim, os "bosques e os parques, tão importantes na visão dos dois urbanistas originais, com o passar do tempo e com a expansão urbana de Goiânia, acabaram sendo comprimidos pelos loteamentos e pela especulação imobiliária". ${ }^{75}$

Resistiu às Forças do Progresso. Fronteiras: Journal of Social, Technological and Environmental Science, v. 8, n. 3, p. 356-378, 1 set. 2019.

${ }^{73}$ Goiânia, 1938, op. cit.; DUTRA E SILVA \& DUTRA E SILVA, 2019, op. cit

${ }^{74}$ DUTRA E SILVA; DUTRA E SILVA, 2019, op. cit., p. 85.

${ }^{75}$ Ibidem. 
Figura 4 - Vista aérea do Lago das Rosas na década de 1940

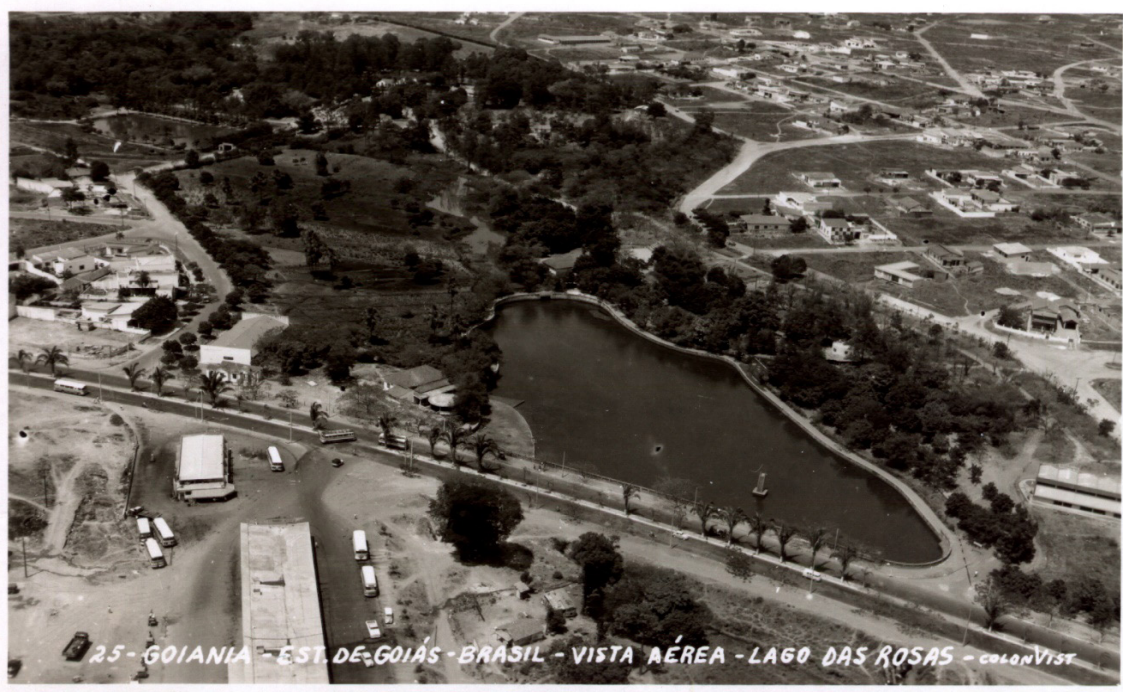

Fonte: Vista área Lago das Rosas década de 1940. Década de 1940. ColonVist. Goiânia - GO. Acervo MIS/GO.

Por intensão de ligar o polo pioneiro (Campinas) ao centro urbano da nova capital, o entorno deste parque foi transformado, recebendo também novas atribuições como espaço urbano. Primeiramente com a instalação do zoológico municipal em 1956 e, posteriormente, com a intensificação de construções verticais para habitação nos anos 1970 e $1980 .{ }^{76}$ Pela figura 4, uma fotografia aérea do Lago das Rosas feita na década de 1940, podemos perceber as alterações paisagísticas realizadas para a transformação das nascentes do Capim-puba em um parque público. A imagem também destaca, na parte inferior, um trampolim construído no lago, que tornava essa área em um balneário e espaço de recreação, mantendo, mais ao fundo, parte da vegetação ciliar original. O registro fotográfico também destaca, na parte inferior, a Avenida Anhanguera margeando o lago, e que passou a ser o principal eixo de ligação entre o bairro de Campinas e o centro de Goiânia. E também esse registro histórico mostra a origens de uma das áreas que iria receber grande investimento do capital imobiliário para a construção de condomínios verticais em torno desse parque. E nesse sentido, o papel político e econômico dos irmãos

${ }^{76}$ CAU-GO, 2013, op. cit 
Coimbra Bueno foi fundamental, pois além de administrarem o processo de expansão fundiária de Goiânia, operaram como corretores interessados na valorização e comercialização imobiliária em Goiânia. ${ }^{77}$ Outras intervenções paisagísticas também ocorreram na área, como o plantio de espécies exóticas na ornamentação e jardinagem do parque. ${ }^{78}$

As edificações que surgiram nos anos 1970 e $1980 \mathrm{em}$ torno dos dois primeiros parques de Goiânia, mais do que caracterizadas pelo seu porte e altura (condomínios residenciais verticais), tinham, também, qualidades de distinção econômica. Ou seja, a justificativa de vender uma "vista da natureza" em pleno meio urbano ao proprietário de um desses apartamentos impulsionava a comercialização de imóveis de maior valor. As orlas das matas e lagos foram, logo, ocupadas por esse tipo de edifícios, elevando-se o valor dos terrenos nas imediações. ${ }^{79}$ Se, no princípio da criação da capital, a áreas verdes eram consideradas uma fonte de produção de insumos para sua construção e manutenção (discurso da mudança da capital) ou de qualidade de vida (fundamentos do urbanismo progressista), a possibilidade de tirar proveito da paisagem fez com que o mercado imobiliário atrelasse ao produto de venda (apartamentos de luxo) um privilegiado ponto de contemplação, fruição e, até mesmo, de elevação social: o parque urbano. Neste sentido, as moradias próximas a estes elementos de natureza, mesmo que modificada, tornaram-se objetos a serem oferecidos aos cidadãos de maior poder aquisitivo, ao mesmo tempo em que representavam boas oportunidades a investidores.

Na figura 5 , referente à planta urbana de Goiânia, produzida pelos irmãos Coimbra Bueno, percebemos a expansão da cidade para além das áreas verdes do projeto original, caracterizada pelos córregos Botafogo (à leste) e Capim-puba (à oeste). Esses dois setores representam as diferentes formas em como as áreas verdes passaram por transformações a partir da cidade sonhada, materializada na ocupação fundiária que não preservou os objetivos originais do projeto. Na parte leste da capital, por exemplo, o projeto original dos parkways acabou não ocorrendo, e por consequência a mata ciliar foi compactada pela ocupação irregular nos leitos do córrego Botafogo. O bosque Botafogo foi preservado em parte, sendo parcialmente ocupado e hoje conta com grande aglomeração ao redor dessa área verde. O setor leste teve uma ocupação imobiliária de caráter mais popular, com os preços dos imóveis e a infraestrutura urbana menos sofisticada.

\footnotetext{
${ }^{77}$ DUTRA E SILVA; DUTRA E SILVA, 2019, op. cit.

${ }^{78}$ Ibidem.

${ }^{79}$ CAU-GO, 2013, op. cit.
} 
Em relação à expansão fundiária na região oeste de Goiânia, ocorreu um tipo de ocupação de maior valorização imobiliária, sobretudo entre as áreas de interligação entre o Bosque dos Buritis e o Lago das Rosas, na junção dos setores Setor Oeste, Bueno e Coimbra. No caso do Bosque dos Buritis, conforme apresentado anteriormente, houve uma diminuição significativa das áreas verdes que apareciam no projeto original de Corrêa Lima (figura 6). Na figura 6, podemos perceber que área original foi reduzida em função da criação de novos quarteirões, mantendo a vegetação típica de veredas para a conservação das nascentes do córrego dos Buritis e a criação dos lagos formados por essas nascentes. E em direção à oeste do Bosque dos Buritis foi formada uma área de grande valorização imobiliária em direção ao Lago das Rosas, que passou a ser uma outra área verde da capital. Os empreendimentos imobiliários nessa região favoreciam a construção de apartamentos e condomínios no setor Oeste (a oeste do Bosque dos Buritis e a leste do Lago das Rosas). Já na parte oeste ao Lago das Rosas, ocorreu a construção de casas de classe média alta nos setores Bueno e Coimbra, recém criados pela empresa dos irmãos Coimbra Bueno.

Figura 5 - Planta de Goiânia produzida pela empresa Coimbra Bueno \& Cia. Ltda., 1947.

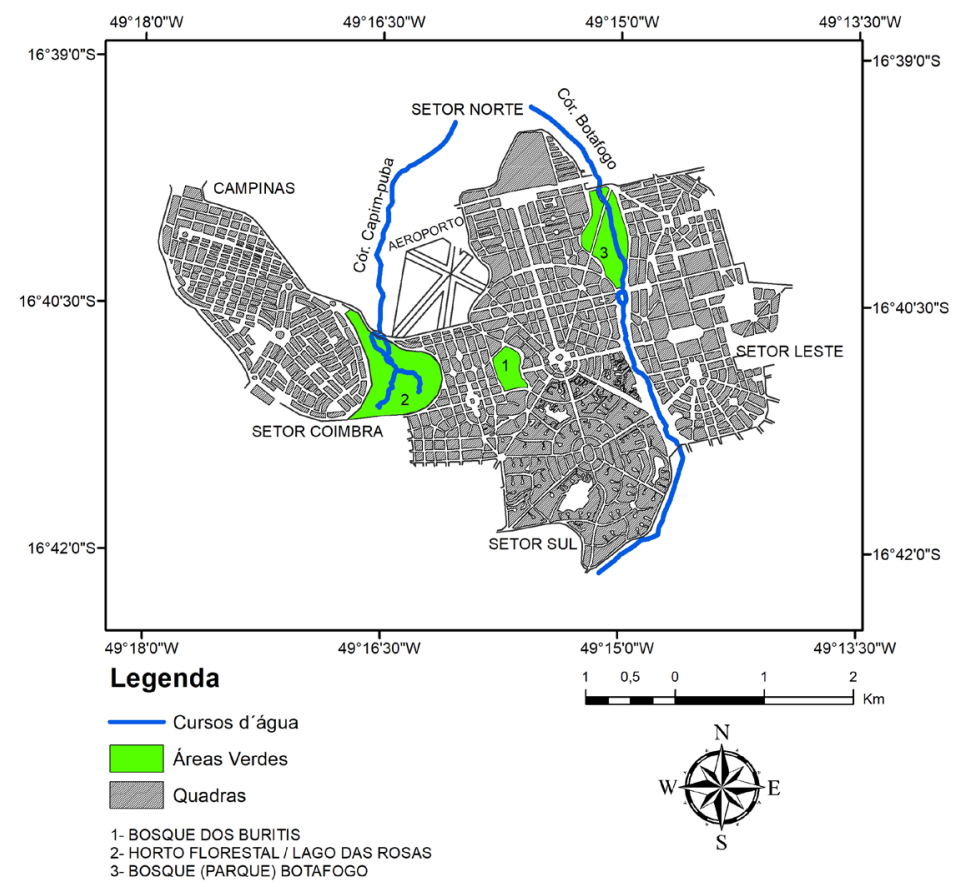

Fonte: Biblioteca da Prefeitura de Goiânia - adaptado pelos autores. 
As matas, rios e córregos, muitos destes presentes no projeto original de Corrêa Lima, passaram a denominar os parques e áreas verdes em Goiânia. Porém, a paisagem destes acabou sendo representada muito mais por lagos artificiais, equipamentos urbanos e construções características das classes mais abastadas da cidade. Os parques passaram a ser consideradas com um elemento de distinção ${ }^{80}$ na topografia social de Goiânia. Uma segunda natureza, ${ }^{81}$ construída e ajustada aos interesses e à "estética da metrópole", foi moldada por edifícios, avenidas e alamedas, sendo agora um novo referencial da paisagem urbana de Goiânia.

Figura 6 - Bosque dos Buritis e os processos de mudanças no projeto original do parque

\section{Região do Bosque dos Buritis}

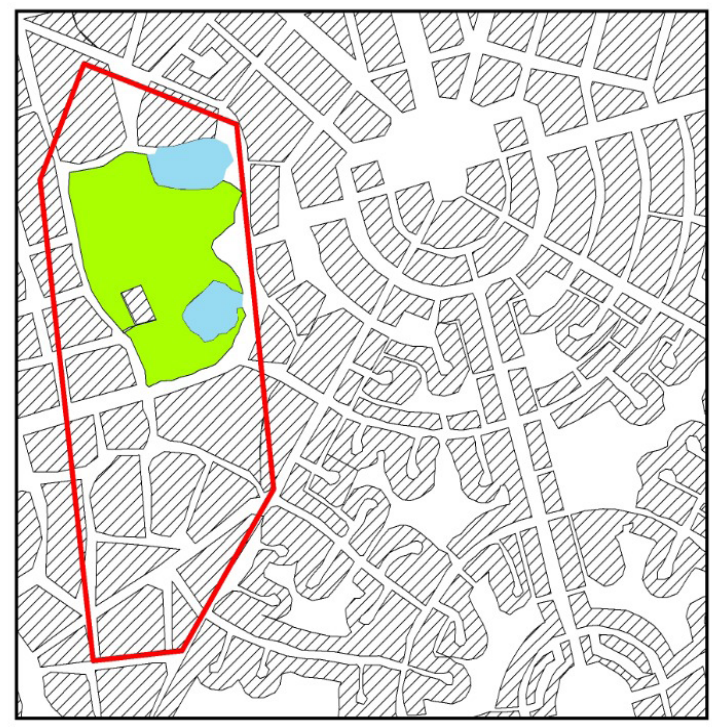

\section{Legenda}
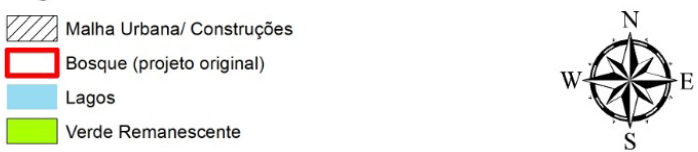

Fonte: Plano Urbanístico de Attilio Corrêa Lima (1937) ${ }^{82}$ / Ortofoto de Goiânia ${ }^{83}$ - adaptado pelos autores.

\footnotetext{
${ }^{80}$ BOURDIEU, 1989, op. cit.; BOURDIEU, 2008, op. cit.

${ }^{81}$ CRONON, 1991, op. ci.

${ }^{82}$ CORRÊA LIMAc, 1937 , op. cit.

${ }^{83}$ Disponível em: http://portalmapa.goiania.go.gov.br/mapafacil/ acessado em 09/07/2020 às 14:32.
} 
Como visto anteriormente, as áreas verdes do projeto original de Goiânia estiveram relacionadas à visão progressista de cidade, na qual esses espaços de cobertura natural estavam associados às questões de abastecimento hídrico, salubridade, lazer e estético. Também que a cidade imaginada buscava o aproveitamento dos seus recursos naturais e em parte a manutenção da cobertura vegetal nativa das matas e dos "capões de buritis". Outro ponto a ser considerado na cidade sonhada são as formas de conservar e valorizar a vegetação ciliar aos cursos d'água, sobretudo por meio da criação de parkways. Estes, por exemplo, foram uma representação apenas da cidade sonhada, cuja realidade foi a ocupação desordenada (ou programada à revelia dos ideais do autor do projeto, como mostra a figura 5) das áreas verdes que compunham grande parte da vegetação características das paisagens originais de Goiânia. E outra observação era a importância dos chamados espaços vazios, no qual as áreas verdes eram incluídas, considerados com dados fundamentais para a qualidade do ar e da salubridade urbana. De forma geral, projeto urbano de Goiânia, nas suas origens, atribuía finalidades paisagísticas e funcionais para as áreas verdes e os recursos hídricos existentes.

Não só a amputação de suas áreas para outros interesses imediatos da ocupação do espaço urbano (como no caso das escolas e da sede do parlamento goiano edificados em áreas ambientais), mas também as oportunidades de negócios lucrativos alteraram a função dos espaços verdes na topografia social da cidade. A paisagem natural (modificada pelos equipamentos de uso público, como pistas de caminhada e lagos) passou a dialogar com as novas intervenções arquitetônicas em volta. De forma geral, a ocupação indevida das áreas verdes (Bosque dos Buritis, Lago das Rosas, Parque Botafoto), além da não implantação dos parkways, são indícios históricos das intervenções do capital especulativo e imobiliário, bem como a ineficiência e escassez de recursos públicos em garantir a manutenção do projeto original de Goiânia na preservação de grande parte das áreas verdes.

\section{Considerações Finais}

O projeto de ocupação do Brasil Central entre as décadas de 1930 a 1940 tinha objetivos muito claros quanto à criação de zonas produtoras de matéria-prima na "periferia" (hinterland) para o abastecimento de bens agrícolas para as regiões "centrais" no sudeste do país ${ }^{84}$. No entanto, pouco analisado, mas também muito representativo, foi o papel histórico da criação de novas

${ }^{84}$ LENHARO, Alcir, A Sacralização da Política. Campinas: Papirus, 1986. 
cidades, compreendidas na época como centros irradiadores da civilização e da "brasilidade" 85 . A construção de Goiânia na década de 1930 fez parte desse contexto, tanto que, a partir a implantação do Estado Novo (1937-1945) a cidade passou a ser considerada como o símbolo urbano da marcha para o Oeste. ${ }^{86}$

O projeto de planificação urbana da nova capital de Goiás deve ser compreendido tanto pela sua relação com a história regional como também na relação da região com contextos nacionais, sobretudo nas discussões envolvendo a cidade como a capital do hinterland.$^{87} \mathrm{E}$ duas questões são fundamentais no sentido de reforçar o caráter regional e nacional da história urbana de Goiânia entre as décadas de 1930 e 1940. A primeira é que Goiânia respondia ao sonho da conquista territorial do Brasil Central no qual, o uso de categorias como hinterland e Oeste, representa parte dessa vontade de domínio e integração geográfica. 0 discurso de Getúlio Vargas em Goiânia, no dia 08 de agosto de 1940 representa o sentido nacional do projeto de ocupação da fronteira, ao afirmar que: "Precisamos promover essa arrancada, sob todos os aspectos e com todos os métodos, a fim de suprimirmos os vácuos demográficos do nosso território e fazermos com que as fronteiras econômicas coincidam com as fronteiras políticas" ${ }^{88}$

A segunda questão refere-se ao fato de que o sonho urbano de Goiânia representa também aspirações regionais, relacionados a agentes sociais que pensaram o ambiente urbano e a forma de constituição desse espaço. E, nesse sentido, o caso especial de Goiânia, esse processo da cidade sonhada para ser a metrópole do hinterland foi sendo transformada pela conjuntura histórica que envolvia agentes do setor público e privado interessados na expansão fundiária e nas pressões do mercado imobiliário sobre as áreas verdes da cidade.

E, evidentemente, as questões políticas da mudança da capital reforçam outra perspectiva do contexto regional, muito já explorado pela historiografia goiana. Dentre os vários estudos relacionados à história urbana de Goiânia ${ }^{89}$

\footnotetext{
${ }^{85}$ TAVARES, Giovana Galvão e DUTRA E SILVA, Sandro. Minérios e outros objetos de história natural: Representações da fronteira no acervo e na criação do Museu Estadual de Goiás na década de 1940. Varia hist., vol.36, n.70, 2020.

${ }^{86}$ DUTRA E SILVA \& DUTRA E SILVA, 2019, op. cit.; DUTRA E SILVA, 2017, op. cit.; DUTRA E SILVA; DUTRA E SILVA; DELLA GIUSTINA, 2018, op. cit.

${ }^{87}$ Discurso do Presidente Getúlio Vargas. Cruzada rumo ao Oeste (improviso inaugurando, em Goiânia, a 8 de agosto de 1940, a associação cívica "cruzada rumo ao Oeste"). In: VARGAS, Getúlio. A nova política do Brasil. VIII. Ferro, Carvão, Petróleo. 7 de agosto de 1940 a 9 julho de 1941. Rio de Janeiro: José Olympio Editora, p. 31-32.

${ }^{88}$ Ibidem, p. 32

${ }^{89}$ BERNARDES, Genilda D'Arc. Construtores de Goiânia: o cotidiano do mundo do trabalho. Dissertação. Mestrado, Ciências Sociais. São Paulo: Pontifícia Universidade de São Paulo, 1989; BERNARDES, Genilda; CAMPOS,
} 
destacam-se questões relacionadas, sobretudo, à modernização urbana, ao projeto mudancista da nova capital e as questões políticas envolvidas. Além disso, outros fatores como as questões sociais da imigração e das relações de trabalho na nova capital fazem parte do contexto historiográfico regional. Um estudo sobre a organização dos espaços urbanos e as questões ambientais é algo que ainda precisa ser ainda mais explorado pela história ambiental. Por isso, as referências relacionadas às áreas verdes e os diferentes conflitos em relação ao projeto sonhado e a expansão fundiária ocorrida, evidencia um novo olhar sobre os processos históricos da urbanização do Brasil Central.

As áreas verdes e a sua relação com os recursos naturais voltados para o ideal de salubridade e higienismo marcaram parte dos discursos e dos planejamentos para a configuração ideal da cidade sonhada como nova capital de Goiás. A existência e a consideração dos diferentes bens naturais serviram como justificativas para a escolha do local para a implantação do projeto urbano de Goiânia. A topografia - que nas antigas cidades brasileiras era uma grande barreira para o desenvolvimento econômico e demográfico - era um indicador favorável por conta das baixas declividades, possibilitando a agilidade das construções, tanto de edifícios quanto de infraestrutura. Destacamos, por exemplo, o papel dos cursos d'água e da vegetação ciliar nos projetos de abastecimento e saneamento da população. Ao mesmo tempo em que está prevista, pela funcionalidade e garantia sanitária, a conservação desses recursos com base na manutenção das áreas verdes existentes na região. 0 solo fértil e a proximidade com a área florestal do Mato Grosso de Goiás e a estação ferroviária em Anápolis reforçava o seu papel urbano como a metrópole do hinterland, incorporando os discursos da expansão da fronteira agrícola para o Brasil Central. As florestas abundantes forneceriam lenha para combustível e madeira para as construções, e o desflorestamento e ocupação das áreas de solo fértil produziriam grãos e outros produtos agrícolas para o abastecimento local e regional.

De certa forma, parte do projeto sonhado pela cidade planejada acabou sendo executado nas décadas que se seguiram. A aplicação dos conhecimentos técnicos e os conceitos do emergente urbanismo europeu deram a Goiânia sua relevância histórica. Contudo, mesmo com um planejamento inicial, fica claro que interesses particulares se sobrepuseram ao projeto original. Os

Francisco Itami. Goiânia: "Sociabilidade na periferia”. Ciências Humanas em Revista, v. 2, n. 1, 1991; MOYSÉS, Aristídes. Contradições de uma cidade planejada no Planalto Central Brasileiro: Segregação Sócio - Territorial em Goiânia. Tese de Doutorado. Programa de Pós-Graduação em Ciências Sociais - PUC/SP, 2001; CHAUL Nasr Fayad, "Goiânia: a capital do sertão". Revista UFG, Junho, Ano XI nº 6, p. 100-110, 2009; CHAUL, Nasr Nagib Fayad. A construção de Goiânia e a transferência da capital. Goiânia, Cegraf/UFG: 1988. 
atrasos nas construções ocasionados por problemas financeiros favoreceram o aparecimento de um oportunismo especulativo que pressionou o crescimento desordenado e ocupando áreas verdes e a sua ressignificação no projeto urbano inicial.

Em relação ao sonho urbano para as áreas verdes, pode-se observar uma grande tensão em relação aos interesses privados do capital imobiliário na Capital. Os terrenos mais localizados na parte central, e posteriormente na expansão para o leste, norte e sul da nova capital, despertou a cobiça de empresas, instituições e população em geral, que acabou descaracterizando o projeto original promovendo a aprovação irresponsável de ocupações irregulares, sobretudo sobre as áreas verdes. $O$ alerta feito por Armando de Godoy sobre a comercialização de lotes ser feita apenas pelo poder público para impedir o desordenamento urbano não foi suficiente para impedir a descontinuidade do planejamento ordenado. Há uma aparente sobreposição entre o público e o privado, podendo ser o motivo para essa ruptura. Citamos como o exemplo o papel dos irmãos Coimbra Bueno, envolvendo interesses públicos e privados em Goiás na década de 1940. A atuação no mercado imobiliário na capital, sobretudo por meio da forte presença na expansão fundiária da capital, acabou sendo um capital simbólico importante para que Jerônymo Coimbra Bueno (1910-1996) fosse eleito como governador de Goiás em 1947. O capital privado e também político, favoreceram na inserção de novos bairros, em desacordo com os projetos originais dos urbanistas Corrêa Lima e Armando de Godoy. ${ }^{90}$

Um grave precedente também surge dessa ação quando regiões apontadas como áreas de parques são fracionadas para o loteamento imobiliário, com a implantação de grandes equipamentos urbanos. É provável que o fato de Corrêa Lima não ter delimitado o que deveria ser preservado (embora no mapa realizado por Godoy em 1938 não delimite a região do setor Oeste ou se limite a representar áreas verdes apenas nos vazios entre as quadras do Setor Sul ${ }^{11}$ ) tenha criado pretexto para que os loteadores ocupassem áreas verdes. Parte destas áreas verdes ainda subsiste, o que pode ser um indício do apreço do goianiense pelas áreas verdes, como um dos traços marcantes da nova capital nos dias atuais. No entanto, a cidade cresceu também para as margens de rios e nascentes e os traçados diversos imprimiram um fracionamento de forma a aproveitar ao máximo os vazios. Assim, os parkways ou

\footnotetext{
${ }^{90}$ DUTRA E SILVA; DUTRA E SILVA, 2019, op. cit.

${ }^{91}$ Ibidem.
} 
greenways apontados por Corrêa Lima não foram implementados, provocando destruição de matas ciliares e poluição dos cursos d'água.

A cidade sonhada, representada nos esboços e nos projetos originais de Goiás, considerava os recursos naturais como elementos fundamentais para a garantia de que a nova "metrópole" cresceria mantendo os seus espaços verdes, abastecida pelo seu hinterland com suprimentos necessários para a sua manutenção. ${ }^{92}$ Posteriormente esses espaços foram compactados e ressignificados, sendo que as áreas verdes perderam parte de seu projeto inicial. Embora esta seja uma preocupação original do projeto de Corrêa Lima, significativa porção das áreas de destaque, no que se trata de parques e espaços verdes, surgiram, mesmo que previamente tenham sido delimitados nos projetos de parcelamento, ${ }^{93}$ de trabalhos paisagísticos realizados em locais degradados pelo crescimento urbano, sendo implantados somente mediante a potencialização imobiliária das regiões onde se localizavam. E, ao mesmo tempo, tais parques passaram a significar como áreas privilegiadas para a valorização econômica de imóveis nessas regiões.

Artigo recebido para publicação em 28/07/2020

Artigo aprovado para publicação em 09/10/2020

\footnotetext{
${ }_{92}$ ALVARES, 1942, op. cit.; SABINO JUNIOR, 1960, op. cit.

${ }^{93}$ A partir da década de 1990, começam a surgir novos parques em Goiânia, aquecendo o mercado de apartamentos de alto padrão e valor econômico.
} 